International Journal of Social Sciences and Humanities
Available online at http://sciencescholar.us/journal/index.php/ijssh
Vol. 1 No. 2, August 2017, pages: $29 \sim 42$
e-ISSN: 2550-7001, p-ISSN: 2550-701X
http://dx.doi.org/10.21744/ijssh.v1i2.33

\title{
Regulatory Framework for Renewable Energy Sources in Ecuador Case Study Province of Manabi
}

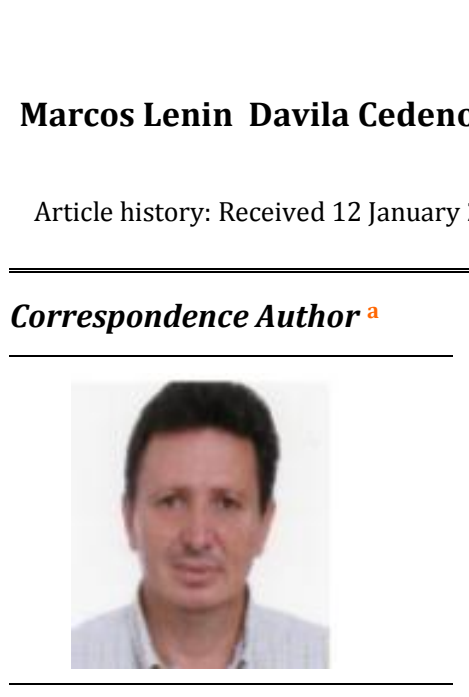

Keywords

Energy policies;

Measures support renewable energies;

Production;

Regulatory framework;

Social relations;

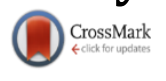

Marcos Lenin Davila Arteaga ${ }^{d}$

\author{
online 31 August 2017
}

\begin{abstract}
The purpose of the research is to expose the nature that, in matters of law and social policy, justifies promoting the elaboration and adoption of a regulatory framework that favors the use of renewable energy sources, for the generation of electricity through case analysis in the Province of Manabí. For the accomplishment of the research study has taken into account a brief theoretical analysis on the fundamentals of the regulatory doctrine, where it exposes the conceptual framework of the law and its necessity for the good development of the social relations that derive from the use of the Renewable sources of energy. A study was carried out of the specific regulatory work carried out at the international level, in order to promote the adequate use of renewable energies, as well as a national study presenting an initial vision for the study and establishment of a specific regulatory framework for the case study of the province of Manabí, as well as a group of policies and support measures that could be adopted to promote the integrated use of renewable energy sources and their contribution to the national energy matrix.
\end{abstract}

e-ISSN : 2550-7001, $p$-ISSN : 2550-701X@ Copyright 2017. The Author. SS Journals Published by Universidad Técnica de Manabí.

This is an open-access article under the CC BY-SA 4.0 license

(https://creativecommons.org/licenses/by-sa/4.0/)

All rights reserved.

\footnotetext{
a Teacher of the career of Electrical Engineering Universidad Técnica de Manabí, Ecuador taliangel270557@gmail.com

b Graduated from a Lawyer at the Catholic University of Guayaquil , Ecuador

c MsC. Lawyer energy regulatory framework, Universidad Técnica de Manabí, Ecuador

d Telecommunications Engineer, Universidad De Especialidades Espíritu Santo. Guayaquil, Ecuador
} 


\section{Contents}

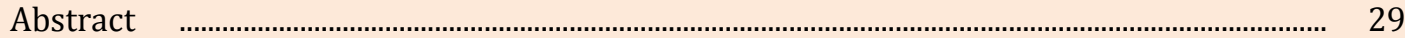

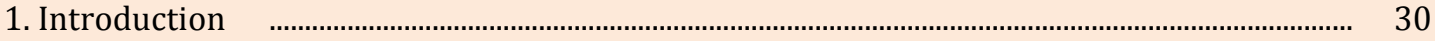

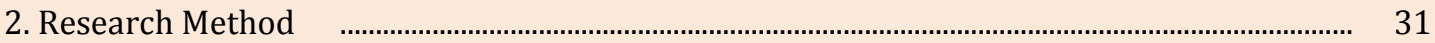

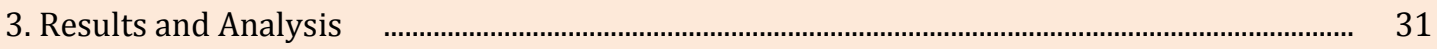

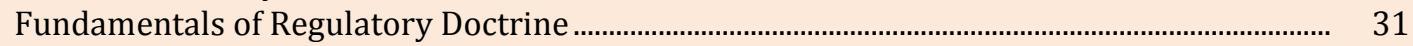

3.1 Sources that feed into the regulatory framework specific to renewable energies.............. $\quad 32$

3.2 Barriers to the development of renewable energy sources..................................................... 32

3.3 Analysis of the regulatory framework of renewable sources from the Ecuadorian view 39

3.4 Case study province of Minabi ................................................................................................... 39

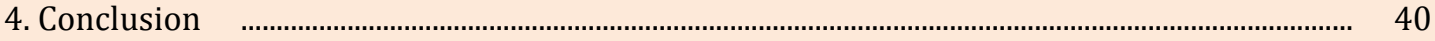

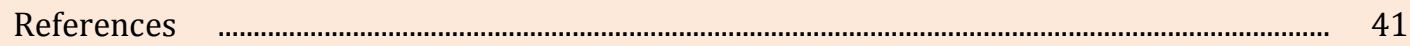

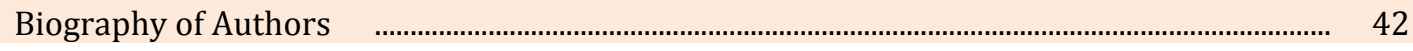

\section{Introduction}

The lack of regulation in the public services and the institutional restructuring, go hand in hand to generate political points of difficult management that can promote the lack of control and encourage the satisfaction of personal interests, above the public interest.

Some authors approach the conceptual framework of public services, such as public or private activities, entities or bodies with legal personality, created by constitution or by law, to provide regular and continuous satisfaction to a certain category of needs in the general interest, Directly, through a concessionaire or through any other legal means subject to a regime of public or private law, as appropriate [1].

The official treatment of the subject of public services has gone through different stages of transformation (from the service provider state to the regulatory state), towards a new legal and institutional regulation, where the function exerted by the public administration is established, as a governing body of the public policies, subject to the public service or general interest, being in consequence of the service of the citizenship without any type of distinctions, privileges or discriminations.

The French jurist Leon Diguit supports the view that when the State provides education, transportation, health, it does not exercise a power of command; even when these activities are governed by a system of public law, the foundation of the state is not sovereignty but the notion of public service.

It must be considered that the modern state is nothing more than a community or corporation of public services, whose agents are the rulers. Therefore, it is to understand that the functions of the state are all those activities that the governors exercise to create, organize and ensure the uninterrupted functioning of public services. Consequently, it can be concluded that for this doctrine, public administration and services are the same things [1].

Article 85 of the Constitution of the Republic of Ecuador establishes that the formulation, execution, evaluation and control of public policies and the provision of public goods and services that guarantee the rights recognized by the Constitution, will be oriented to make good living effective and will be formulated from the principle of solidarity.

Later in the Charter it article 227 states: "Public administration is a service to the community that is governed by the principles of effectiveness, efficiency, quality, hierarchy, deconcentrating, decentralization, coordination, participation, planning, transparency and evaluation [2]. Correspondingly on October 4, 2010, the Public Service Organic Law [3] was enacted.

The public service nature of electricity services is confirmed in accordance with article 314 of the Constitution of Ecuador, when it is established that the state will be responsible for the provision, inter alia, of the public electric power service [3]. The name of the Organic Law of the Public Electric Power Service infers the public character of this service [2]. 
The Organic Law of the Public Service of Electric Energy regulates in detail what is related to the generation, transmission, distribution and supply of electricity from conventional sources. However, the specific regulations for the use of non-conventional energy sources are not specified, leaving a legal vacuum in this sense, which must be covered by the implementation of a standard that protects the use of this energy source and its implementation Service in the interest of sustainable development of society.

On the other hand, the serious damage to the natural environment caused by traditional energy policies, where energy generation and waste has played a determining role, has led to the realization that, beyond the controversial debate about its causality, And the need to maintain economic and social development, without compromising the enjoyment of an adequate environment for future generations [4].

The objective of this work is to offer a critical analysis of the evolution of the regulatory framework for renewable energy sources at international level and Ecuador itself, highlighting the values linked to the energy policy developed in recent years by a group of countries that Undertook the path of the change of the energy matrix applying sustainable solutions for the society, so that they can offer the foundations that in the matter of law, allow promoting the elaboration of a specific legal body that protects the proper use of the renewable sources of energy, Mainly non-conventional resources.

In this sense, it is part of the analysis of the Organic Law of the Electric Power Public Service of Ecuador, unraveling the void that in legal matters exists in relation to the regulation of renewable energy sources and especially with non-conventional resources. The same method can be applied in the field of energy policy.

\section{Research Method}

The research methodology used is part of the general method of dialectics as the basis and foundation of other general methods of science, which allowed to analyze the evolution of the regulatory framework of renewable energy sources, taking into account the specific historical moment in which Was developed each event, as well as determine the close relationship with non-conventional sources and what represents their use for the sustainable development of society.

The research also relies on the inductive method, allowing the existence of the content of the object of study, obtaining its own conclusions, allowing to deduce the essences, the causes and the reasons for the final proposals and recommendations.

The juridical theoretical method, for the examination of the diverse classic and modern theories, that prevail in the doctrine, with respect to the juridical values and the role that they play in the social development. Likewise, the comparative legal method that allowed to evaluate the regulation of renewable energy sources in other legal systems at international level, and then to compare them with that of Ecuador.

The research is complemented by the deployment of investigative techniques for reviewing documents, texts, legislation, to obtain the adequate and truthful information that implies the arrival of certain considerations on the subject. All of the above was applied in order to unveil the essence of the scientific problem, in the processing of information and the definition of the system of central and operative categories. In addition to reaching the corresponding conclusions, which may be useful in the light of the study proposed.

\section{Results and Analysis}

\section{Fundamentals of Regulatory Doctrine}

Conceptually the word law of the Latin lex is considered a rule or norm. It is a constant and invariable factor of things, which is born of a first cause. Laws are, on the other hand, the relations existing between the elements that intervene in a phenomenon.

In the field of law, the law is a precept dictated by a competent authority. This text requires or prohibits something in line with justice and for the good of society as a whole [5].

Cedeno, M. L. D., Arteaga, M. G. D., Perez, A. V., \& Arteaga, M. L. D. (2017). Regulatory framework for renewable energy sources in Ecuador case study province of Manabi. International Journal of Social Sciences and Humanities, 1(2), 29-42. https://doi.org/10.29332/ijssh.v1n2.33 
Other authors point out that the law refers to a rule, a norm, a principle, a precept. Failure to comply with the law brings penalties. Hence its existence as a norm obeys the need to rule and correct the social behavior of human beings. The word law can also be used to refer to a law or to all laws [6].

Particularly in the Ecuadorian Civil Code in Article 1 specifies that: The law is a declaration of the sovereign will, manifested in the form prescribed by the Constitution, commands, prohibits or permits. Laws are generally mandatory rules of common interest. In article 2 of the body bequeath is endorsed: The custom does not constitute law except in cases where the law refers to it [7].

That way you can understand the key importance of establishing laws for the proper functioning of a society of rights, although there are lawyers who often ignore the importance of regulatory quality so that at some point may seem excluded from the object and of the practice of law [7].

It should be considered that the objective of regulatory quality goes beyond guaranteeing the validity of the measures adopted and aims above all to ensure greater effectiveness in terms of effective compliance with current regulations and the achievement in the practice of results consistent with Purposes for which each regulatory measure has been adopted [7].

Regulatory activity seeks to achieve greater economy in the sense of efficient regulation in economic and social terms, optimizing the use of state resources and the recipients of regulation, creating a favorable environment for the exercise of activities Administration and the exercise of the rights and freedoms of individuals.

On the other hand, based on speed, the regulatory activity must, therefore, be conducted and lead to regulatory measures, whose application implies greater diligence, agility, eliminating excessive and costly costs in money and time, relying on the extent of Possible, in systems based on information and communication technologies [7].

But in spite of the clarity of the ideas expressed above, it is common to hear that the ways of fact are more effective than those of the law. While some cases might support such an immediacy, a human group led by that path is condemned to anarchism, insecurity, violence, misery, inequity, and desolation, to the same miserable, unhappy and sad condition in which it was Human species before the establishment of the law.

In fields sown with insecurity and uneasiness, progress, peace, well-being, happiness can not germinate. The rule of law and the rule of law is still a requirement for sustainable economic progress and so is for equality and social equity [8].

Law is the most exalted creation of humanity on its path from barbarism to harmonious coexistence, freedom, and peace. The law makes possible the exercise of freedom and civilized life. No limits on behavior accepted by all, freedom would perish drowned out by brute force and coexistence plunged into chaos and insecurity in an unpredictable violence. When mankind was able to conceive and formulate general and impersonal rules valid for all regardless of culture and individual thoughts, to which it is promised and owed, it was able to overcome its connatural conflicts without resorting to oppression and violence [8].

All this leads us to think how important it is the law to regulate certain social relations, such as those that occur during the use of renewable energy sources and very particularly unconventional character.

\subsection{Sources that feed into the regulatory framework specific to renewable energies}

It can be affirmed that the regulatory policy of renewable energies was born practically with the Roman Law and is that they were the first used by the man as the subject of the society.

In the Justinian Code on the guarantee of the rights to the sun, a regulation was inserted into the Roman law stating that "if an object is placed in a way to conceal the sun from a heliocaminus, it must be said that such an object creates shadow in A place where sunlight is an absolute necessity. This is in violation of the right of heliocaminus to the sun [9].

Already in earlier times and because of the need to take advantage of solar energy in Greek architecture, Socrates had pointed out that the ideal house should be cool in summer and warm 
in winter, explaining that "in houses facing south, the sun penetrates through the In the winter, while in summer the described solar arc rises over our heads and above the roof, so that there is shade and thus was collected in the regulations of ancient Greece [9].

Also in very ancient times and running the year 212 BC, there is knowledge about the application of solar energy, in this case for warlike purposes, when Archimedes used incendiary mirrors to destroy the Roman ships that surrounded Siracusa.

Later in the thirteenth century, Roger Bacon proposed to Pope Clement IV, a regulation for the introduction of solar energy for belligerent purposes, based on the use of solar mirrors in the Crusades, for "this mirror would ferociously burn anything on which Focus. "It follows that Arquimides intended to use such mirrors to set fire to cities, fields, and weapons [9].

For millennia renewable sources were the preferred suppliers of energy to society. Mainly the Sun to warm homes, as well as for the drying of agricultural and medicinal products; The wind widely used in the navigation and then to operate technologies destined to grind grains; The water currents to transport wood and to operate the mills used for grinding grain [10].

The great historical leap took place at the end of the eighteenth century, the Industrial Revolution was a strong increase in the demand for raw materials and energy, the most used until then wood, was displaced by fossil fuels, first by coal, later For oil and natural gas and in the second half of the 20th century with nuclear energy [11].

At the end of the nineteenth century oil and nuclear fuels appeared as elements that would facilitate the eternal solution to the problems of development in terms of their energy needs, the design of the prevailing political and economic system, based on a race uncontrolled by consumption, made That these sources would be considered as unlimited and infinite, without assuming the environmental impact associated with the intensive exploitation of hydrocarbons and nuclear fuels, as well as the physical exhaustion of the reserves of these resources.

Until then, science had not demonstrated the environmental effects and accelerated depletion of natural resources that had already accumulated man's predatory and irresponsible activity, so there were neither ethical nor scientifically grounds for such concerns. Unfortunately, this selfish and irresponsible current persists in most of the human beings of our day.

The extraordinary development of technology and science attained by humanity in the twentieth century demonstrated the ambivalence of the creation of the human mind. The sublime and positive has seen the light next to the negative and despicable. This policy has led the human species to live in two worlds: one endowed with every possible comfort and another that faces every day a desperate struggle for survival and against hunger, illiteracy, and disease; A first world that has achieved this condition on the basis of the sustained impoverishment of a third world contaminated, desertified and impoverished in its natural resources [12].

The technological take-off of industrial society imposed as a paradigm to produce more to have greater benefits, that is, to prioritize energy production over its effects and consequences, conventional technologies increasingly modern, allowed during the first half of the twentieth century The consumption of energy will be triggered to levels practically immeasurable, being the cost of the fuels very cheap and affordable. Until the 1970s, energy consumption doubled every ten-year period, or what is the same, every fourteen-year period humanity consumed as much energy as its previous history [11].

It is argued that the specific regulatory framework for renewable energy sources at the international level is a child of the environmental movement that emerged at the United Nations Conference on the Human Environment in Stockholm, Sweden, on June 5, 1972, and Constitutes its main source. In this conclave came alive the principles and pronouncements that later became profiled and find their most finished expression in the legal norms that constitute the Environmental Law today. The Stockholm Declaration was derived from this international meeting, which is the first approach to the environmental issue in the international area and identifies the paths through which the study of this problem must be carried out, as well as the focal points in which the Right in the analysis and solution of the problems that are presented to man.

Cedeno, M. L. D., Arteaga, M. G. D., Perez, A. V., \& Arteaga, M. L. D. (2017). Regulatory framework for renewable energy sources in Ecuador case study province of Manabi. International Journal of Social Sciences and Humanities, 1(2), 29-42. https://doi.org/10.29332/ijssh.v1n2.33 
In spite of the extraordinary environmental movement that had awakened, technological development continued without considering the great damage that had already been caused to the stability of life on Earth. In 1984 a group of German scientists detected signs of deterioration in forests, although the problem of acid rain was already well known; This year it was reported that the earth lost eleven million hectares of forest annually and in 1985 two British scientists reported finding a hole in the ozone layer over Antarctica [12].

On 16 June 1987, the Governing Council of the United Nations Development Program (UNDP) adopted the decision to submit to the General Assembly the Report of the World Commission on the Environment, under the title of Our Future Common, also known as the Brundtland Report [14]. The document proposes to create an environmental strategy that is powerful along with socially and environmentally sustainable, but not any development, not a development at any price, not a development imitating the failures of the currently developed countries. It proposes the undertaking of a process of changes in the exploitation of resources. It is recognized that the emissions of polluting gases responsible for the greenhouse effect come from the combustion of fossil fuels.

Currently, more than $60 \%$ of the electricity consumed in Ecuador is of hydraulic origin; But there are areas that are far from the hydroelectric power stations, where it is not technically convenient to supply renewable energy from the use of water.

The electricity consumed in the province of Manabí has a thermal origin based on the use of petroleum as fuel, presenting a high generation cost that increases due to the pollutant potential of the fuel burning. On the other hand, there is a part of the population that still does not have the electricity service because they are in isolated areas of the National Interconnected System.

The province of Manabí has good potential for solar energy and a certain wind potential in some specific points of the territory, which could be exploited using small technologies in the mode of distributed generation. This situation can be added to the existence of a biomass potential that has not yet been sufficiently studied due to lack of economic resources to ensure its study and evaluation.

At present, there is no regulatory framework or policy that includes support measures aimed at the integrated use of renewable sources for energy generation, and therefore its decentralized use is stagnant.

There is a level of alternatives and solutions that can be addressed in the national and local framework, which due to the nature and complexity of the social relations that derive from its application, should be taken into account by the legal system and the adoption of national policies And provincial governments that are able to support compliance with legislation on the integrated use of renewable energy sources.

In the National Plan for Good Living 2013-2017 [15] in chapter 5.1.4. "In parallel with the implementation of large hydroelectric projects, in 2030 the supply of electricity will be complemented by the implementation of small power generation projects with renewable sources such as: photovoltaic, wind, Biomass and hydroelectricity in areas close to consumers, and with participatory management schemes by Decentralized Autonomous Governments, community organizations and the private sector. These projects make available renewable energy for local productive uses and the interconnected system, which allows local employment, optimize the use of natural resources, diversify the territories in the generation of electricity and reduce technical losses in the transmission of electricity.

\subsection{Barriers to the development of renewable energy sources}

In recent years, some Latin American countries with sufficient solar and wind resources have promoted the use of these renewable sources of energy, but despite the efforts the contribution of renewables in the energy matrix has not increased enough and Electricity generation continues to be based mainly on thermal power plants or large hydroelectric plants, which are associated with losses and environmental impacts that make it unsustainable. 
The answer to this problem involves a series of variables related to the political, legal, administrative, economic, financial, technical, social and environmental barriers that reduce or inhibit the development of renewable electricity generation projects [14].

These barriers first need to be identified and critically examined, so that they can then be removed through different strategies and promotion policies, as an indispensable condition for the development of renewable energy sources in general. Although there are marked differences between Latin American countries in the energy sector, many similarities can be found regarding the type of barrier that the development of renewables faces.

Table 1 shows a summary of the main barriers to the development of renewable sources of energy [14].

Table 1

Barriers to the development of renewable sources of energy

\begin{tabular}{|c|c|}
\hline Types of barriers & Manifestations \\
\hline POLICIES & $\begin{array}{l}\text { a) Definitions and policy decisions aimed at the promotion and } \\
\text { implementation of renewable systems in an integrated manner. } \\
\text { b) Energy planning with little contribution of renewable energies in } \\
\text { the energy matrix. } \\
\text { c) Weak investment in innovation and transfer of renewable } \\
\text { technology. }\end{array}$ \\
\hline LEGAL & $\begin{array}{l}\text { d) Legal insecurity for investors. } \\
\text { e) There is no adequate legal framework governing social relations } \\
\text { derived from the use of non-conventional renewable energies. } \\
\text { f) Regulations that favor the centralized system of generation and } \\
\text { supply of electricity. }\end{array}$ \\
\hline $\begin{array}{l}\text { ECONOMIC AND } \\
\text { FINANCIAL }\end{array}$ & $\begin{array}{l}\text { g) Strong subsidies to fossil energy. } \\
\text { h) High initial capital costs for the development of renewable } \\
\text { sources. } \\
\text { i) Unfavorable standards for the price of power. } \\
\text { j) Rules unfavorable to the price of energy. } \\
\text { k) Environmental externalities not considered in fossil plants. } \\
\text { l) High perception of uncertainties and risks in the investment. } \\
\text { m) The small size of the renewable market. } \\
\text { n) Non-recognition of life-cycle analysis for the determination of } \\
\text { economic feasibility. } \\
\text { o) Speculative prices in the Latin American energy market for } \\
\text { renewable technologies. }\end{array}$ \\
\hline $\begin{array}{l}\text { TECHNIQUES AND } \\
\text { REGULATORY }\end{array}$ & $\begin{array}{l}\text { p) Poor evaluation of the renewable resource. } \\
\text { q) Little recognition of distributed generation mode. } \\
\text { r) Restrictions on siting and construction. } \\
\text { s) Low technical, commercial and information capacity. } \\
\text { t) Cumbersome administrative procedures for investments in } \\
\text { renewable sources. } \\
\text { u) Few technical regulations of operation. }\end{array}$ \\
\hline INDUSTRIAL & $\begin{array}{l}\text { v) Little local industrial development due to the use of renewable } \\
\text { sources. }\end{array}$ \\
\hline
\end{tabular}

Cedeno, M. L. D., Arteaga, M. G. D., Perez, A. V., \& Arteaga, M. L. D. (2017). Regulatory framework for renewable energy sources in Ecuador case study province of Manabi. International Journal of Social Sciences and Humanities, 1(2), 29-42. https://doi.org/10.29332/ijssh.v1n2.33 


\begin{tabular}{|l|l|}
\hline & w) $\begin{array}{l}\text { Weak adaptation of Environmental Standards in terms of the use } \\
\text { of renewable sources. }\end{array}$ \\
SOCIAL AND & x) $\begin{array}{l}\text { Little information, dissemination, participation and social } \\
\text { acceptance based on the use of renewable sources. } \\
\text { ENVIRONMENTAL }\end{array}$ \\
y) $\begin{array}{l}\text { Weak evaluation of social and environmental benefits provided by } \\
\text { the use of renewable sources. }\end{array}$
\end{tabular}

\section{As for the barriers outlined above, the following can be noted}

1. Definitions and policy decisions aimed at the promotion and implementation of renewable systems in an integrated manner. This barrier can be seen clearly in countries that have fossil and hydraulic resources, where there is no firm practice in favor of the integrated development of renewable sources. All this happens despite the fact that in political speeches, the theme of renewable energies and sustainable development are always present.

2. Energy planning with little contribution of renewable energies in the energy matrix. In some countries, this phenomenon is a direct consequence of the lack of renewable development so that in the planned future energy matrix the contribution of generation from renewable sources is poor. In the case of Ecuador, a high development of the conventional renewable source has been favored by taking advantage of the extraordinary hydraulic power that exists in the central part of the country, however, the participation of other sources is symbolic and in the case of the non-conventional one is Null.

3. Weak investment in innovation and transfer of renewable technology. This is a phenomenon practically generalized in Latioamérica since in general a very low budget is dedicated to technology innovation, because the resources generally go to solve the urgent, without having room to maneuver to plan the future.

4. Legal insecurity for investors. It is a constitutional principle that jurisprudence has interpreted by emphasizing that on this principle rests the legitimate expectations of those who expect acts and behavior of the Administration reasonably consistent and aligned with those that precede it, without this means that the legal system must remain unchanged. Legal certainty is fundamental for entrepreneurs and investors to act in the direction of deciding where the investments are going.

5. There is no adequate legal framework governing social relations derived from the use of non-conventional renewable energies. In many countries utilities still, have virtually complete control over the production and distribution of electricity. Under these circumstances, in the absence of a legal framework, independent energy producers may not be able to invest in renewable energy facilities and sell energy to the grid or to third parties under so-called "electricity purchase agreements."

6. Regulations that favor the centralized system of generation and supply of electricity. In some countries, energy legislation makes no mention of the model of distributed generation and in practice favors the development and consolidation of the centralized system of generation and distribution of electricity, although the disadvantages, of centralized systems in terms of energy losses and their environmental impacts are known technically. In the Organic Law of the Public Service of Electric Energy, the only mention is made of Distributed Generation on one occasion, leaving a deep legal vacuum that allows to properly regulate the social relations that derive from this way of generating and distributing the electricity according to the Benefit of society.

7. Strong subsidies to fossil energy. Although the political discourse of Latin American governments recognizes the need to promote the development and consolidation of renewable energies, the subsidy to fossil energy remains the preferential expenditure in the state budget. In Ecuador, a strong impetus has been devoted to the development of conventional hydroelectric power; But the subsidies for the rest of the renewables in an integrated way has been symbolic. 
8. High initial capital costs for the development of renewable sources. The cost of operating renewable energy can be very competitive compared to conventional ones when considering life cycle analysis and externalities. In contrast, the initial cost of an investment based on renewable energy may be relatively higher than the cost of a conventional thermal, so it will require financial support. In addition, as the product is riskier, the financial market will demand a higher profit.

9. Unfavorable standards for the price of power. Renewable wind and solar energy sources are of the intermittent type, so the generated power levels can not be fully controlled. As a consequence, they do not ensure a certain power at a given moment (firm power) and it is a very possible that they will be exempt from receiving a powered payment connected to the grid. If renewable energies could work in a distributed generation framework (low power and close to demand) they do not require transmission lines, nor the inclusion of other transformation technologies that increase losses. However, this beneficial fact is not considered.

10. Rules unfavorable to the price of energy. In Ecuador, a flat rate at the national level is established by legal regulation for the payment of the electric tariff, setting the price of $\mathrm{kWh}$ served for the residential sector between 0.10 and 0.11 cents of the dollar and for the institutional sector in about 0,07 cents, however the actual cost of $\mathrm{kWh}$ served in the province of Manabí where the generation is basically thermal, oscillates between 0.40 and 0.50 of the kWh dollar.

11. Environmental externalities not considered in fossil plants. The environmental impacts caused by fossil combustion result in a real cost to society in terms of human health, forest, land, fishing, civil infrastructure (acid rain) and climate change related costs ( greenhouse effect). The cost of environmental externalities is very difficult to assess and will depend on the assumptions made. The ExternE study, a tool that quantifies the social and environmental costs of the use of fossil resources, ranged between $1 \%$ and $2 \%$ of the European Union's Gross Domestic Product (GDP). The costs of climate change. The study concludes that if such external costs are integrated into the European electricity bill, the price of kWh produced with fuel or coal should double, while that produced from natural gas would be increased by at least $30 \%$.

12. High perception of uncertainties and risks in the investment. It is proven that renewable energies can still be perceived as high risk if you have little experience with them in any application or if there is a lack of visible facilities. These perceptions can make it difficult to obtain financing, increase required rates of return, have lower capital availability, and establish stricter requirements in technology selection and resource assessment. Therefore companies can resist developing, acquiring and maintaining technologies that are unfamiliar to them. As a result, the financial community, which is prone to avoid risks, has often been reluctant to invest in renewable sources. In addition to this there may also be a lack of tax or tax incentives for those who opt for these technologies.

13. Small size of the renewable market. If the market for renewable energies is small and with little dynamism, it will take longer to develop.

14. Non-recognition of life-cycle analysis for the determination of economic feasibility. In many cases the life cycle analysis is not considered during the realization of the economic feasibility studies and in these conditions the renewables are at a disadvantage to the energy market. It is not taken into account that the conventional generation devices present an initial value in the market and after they are acquired it is necessary to continue to spend economic resources to ensure their operation (fuel costs, lubricants and maintenance), as well as the costs that derive Of externalities. However, renewable sources may present relatively higher home prices than conventional technologies, but over time costs recover relatively quickly, operating at virtual cost equal to zero for fuel and environmental costs are diametrically lower.

Cedeno, M. L. D., Arteaga, M. G. D., Perez, A. V., \& Arteaga, M. L. D. (2017). Regulatory framework for renewable energy sources in Ecuador case study province of Manabi. International Journal of Social Sciences and Humanities, 1(2), 29-42. https://doi.org/10.29332/ijssh.v1n2.33 
15. Speculative prices in the Latin American energy market for renewable technologies. In Ecuador, the importation of renewable technologies is tax free upon entering the country. However, prices in the domestic energy market represent three times and sometimes up to four times the prices of the international market for the technologies.

16. Poor evaluation of the renewable resource. Before starting any renewable project it is essential to carry out a measurement campaign aimed at knowing the true potential of the resource. The minimum time to perform this action is one year. In general, in countries that have no tradition of using renewable energies, these measurements do not exist, which affects the quality and reliability of renewable resource assessments.

17. Little recognition of distributed generation mode. The most efficient way to take advantage of non-conventional renewable resources corresponds to the Distributed Generation mode with connection to the low voltage network, since losses are avoided and facilities are economically saved, as they do not need new power lines or transformation capacities, However in the energy regulations the use of the renewable resource is privileged in the model of centralized generation. In the case of Ecuador in the Organic Law of the Electric Power Public Service, only a very brief mention is made of the Distributed Generation, leaving a legal vacuum related to the regulation of the social relations that derive from this mode of production and distribution of electricity.

18. Restrictions on siting and construction. Planning departments and inspectors may not be familiar with renewable energies and may not have the procedures to deal with their location and permit management. Restrictions result from considering land use impacts on agriculture, recreational activities, landscapes, development interests, etc. For example, wind farms should be carefully examined for specific site-related environments along migratory and coastal zone routes, visual impacts, audible noise, among other issues.

19. Low technical, commercial and information capacity. Markets work best when everyone has low-cost access to good information and knowledge. However, in specific markets such as renewable energy, qualified technical, administrative and commercial personnel may not exist in the number required, nor present sufficient knowledge and information in relation to technology, economics, costs and Benefits, maintenance requirements, installation services, etc. This situation can increase the perceived uncertainty and block the decisions in favor of the use of the renewable energies.

20. Cumbersome administrative procedures for investments in renewable sources. The management of carrying out a renewable project from birth to the cradle, can be very complicated and discouraging, due to the multiple steps that must be followed, the different offices to go, the countless documents that must be presented and the Management time to be invested. All this represents a real brake on the will to take advantage of renewable resources

21. Few technical regulations of operation. Renewable systems have different characteristics than conventional ones in terms of their insertion into the electricity grid and their subsequent operation, both under normal and transient conditions. The lack of experience of traditional electric system operators raises great doubts about how to handle the intermittency of renewable energies and how to deal with contingencies. This lack of knowledge translates in general, in the absence of technical regulations that contemplate the contribution of renewable energy to the network.

22. Little local industrial development due to the use of renewable sources. In general, the role of the renewable energy industry in Latin America is still very insignificant. This is motivated by the many barriers that are being analyzed: political decisions, development laws, economic and financial support, plans for renewable energy installations of a certain magnitude, market sizes, regional energy integration, etc.

23. Weak adaptation of environmental standards in terms of the use of renewable sources. Environmental standards are mainly aimed at the evaluation of conventional systems. In the face of the emergence of renewable energies, there are no specific rules for these applications, ie the procedures that determine whether the environmental impact of this 
new activity is in accordance with current standards, setting compensation, repair or mitigation measures for possible impacts, However, do not take into consideration the beneficial impacts that are derived, which in the case of renewable are the largest.

24. Little information, dissemination, participation and social acceptance based on the use of renewable sources. The level of information that has, in general, the population is very low and there is no policy of diffusion of the characteristics of the renewable energies. This lack of knowledge can lead to a population being able to refuse to install a renewable system. It is fundamental, therefore, that the various actors of society are involved with all aspects related to renewable sources. It's active participation will depend to a large extent on the subsequent acceptance and completion of different projects. When there is no citizen participation and information about a specific project, it will be very difficult to accept.

25. Weak evaluation of social and environmental benefits. This aspect is linked to the previous element, in which the ignorance of the population of the multiple direct and indirect benefits of a renewable project is relegated to the strong sense of uncertainty that comes with the installation of something different.

\subsection{Analysis of the regulatory framework of renewable sources from the Ecuadorian view}

The implications associated with the introduction of new technologies related to energy development must be analyzed multilaterally, in his work "Renewable energy: its role in cooperation and in the elaboration of a model of sustainable development", emphasizes the importance of this dynamic vision in order to facilitate both integration and its Maintenance, stating that (...) "when thinking about the introduction of a new energy source, we must think of energy systems, which, in addition to the introduction of energy itself, facilitate the conditions for a sustainable use of energy" [16].

The analysis made so far shows that without the articulation of a specific regulatory framework for renewable energies, especially non-conventional resources, and the delineation of a set of support mechanisms and measures, aimed at favoring the diversified introduction of technologies that take advantage of Renewable sources of energy, it is very difficult to achieve the extraordinary political will deployed by the state to transform Ecuador's energy matrix, based on an efficient, technically reliable and sustainable electricity industry, based on the integrated use of sources Renewable.

\subsection{Case study province of Manabí}

In the case of a study in the province of Manabí, where electricity costs are usually the highest in the country, given the place, it occupies in the radial electrical system, which is very distant from hydraulic generation centers and with thermal plants currently generate a considerable amount of electricity. The mechanisms and support measures that may be adopted may be effective until the year 2020 and should aim at:

a. Reduce the share of electricity generated from petroleum, up to a maximum of $40 \%$ of the total energy contribution.

b. Increase the participation of renewable energies in the total contribution of electric energy by up to $60 \%$.

c. Ensure the gradual increase in the share of photovoltaic solar energy connected to the low voltage grid in the model of distributed generation, in the total electricity supply, so as to reduce losses, increase efficiency, improve The voltage profile in the lines where the technology is connected, save oil and reduce $\mathrm{CO}_{2}$ emissions to the atmosphere.

d. Guarantee the participation of small power wind power in the sites identified with wind potential usable with such technologies.

e. Give way to the legal recognition of private independent energy producers at the expense of the use of non-conventional renewable sources.

Cedeno, M. L. D., Arteaga, M. G. D., Perez, A. V., \& Arteaga, M. L. D. (2017). Regulatory framework for renewable energy sources in Ecuador case study province of Manabi. International Journal of Social Sciences and Humanities, 1(2), 29-42. https://doi.org/10.29332/ijssh.v1n2.33 
f. Provide access to the guaranteed and priority network for independent energy suppliers using renewable sources.

g. Provide a special tariff for the payment of energy to independent suppliers, which is a stimulus to investment in renewable sources.

h. Promote and prioritize the financing of projects focused on the study and research of the potential of renewable energy sources, especially geothermal, tidal and biomass. Specially stimulate the development of research in the universities of the country, so that in each place is investigated the use of the energy resource that is available and encourage the balanced development of the different regions of the national territory.

i. Promote and prioritize the financing of projects aimed at technological assistance, for the use of primary energy contained in renewable sources, for heating fluids, water pumping, drying products and other energy needs.

j. To elaborate and implement in the territory of the province a strict efficiency regulation for the energy consumption of all household appliances, buildings, and vehicles.

$\mathrm{k}$. At the same time promote the creation of sustainable transport strategies.

\section{Conclusion}

1. The research carried out has made it possible to provide the necessary information to promote the need to articulate a regulatory framework that favors the use of nonconventional renewable energy sources, promoting the preservation of natural resources, saving oil and reducing Environmental impact derived from the generation of energy.

2. The work allowed the exposition of the experiences that have been put into practice at the international level, with the aim of achieving diversification of the energy matrix at the expense of the adequate use of renewable energy sources, for which it was necessary to articulate a Regulatory framework integrated by various categories of legal bodies, as well as the broad deployment of policies and measures to support renewable energy.

3. The paper provides an initial vision for the study and establishment of a specific regulatory framework, as well as a set of policies and support measures that could be taken to promote the integrated use of renewable energy sources and their contribution to National energy matrix.

\section{Acknowledgements}

Our deep and sincere gratitude were presented to God for having granted us the ability and the opportunity to complete this paper. As well as, We have much appreciated to my friends for their support, suggestion, contribution in finishing this research. We would like thanks to Prof. Maria that has given me a good advisement. Last but not least, We dedicated our dreadful thank to my friend who those as editor in ScienceScholar Journal.

\section{References}

1. Adetunji, A. T., Adetunji, A. V., Adeleke, E. O., \& Madubuike, S. C. (2017). Deregulation: The Effect of Market-led Approach to Nigerian Universities Management. International Journal of Social Sciences and Humanities (IJSSH), 1(1), 1-8.

2. Amerta, I. M. S. (2017). The Role of Tourism Stakeholders at Jasri Tourism Village Development, Karangasem Regency. International Journal of Social Sciences and Humanities (IJSSH), 1(2), 20-28.

3. Asamblea General. (1987). Informe Bruntland. Informe de la Comisión Mundial sobre el Medio Ambiente y el Desarrollo. Nota del Secretario General. Naciones Unidas. Cuadragésimo segundo periodo de sesiones. Tema 83 e) del programa provisional, Consultado el 23 de agosto de 2016. https://es.scribd.com/doc/105305734/ONU-Informe-Brundtland-Ago-1987-Informe-de-la-ComisionMundial-sobre-Medio-Ambiente-y-Desarrollo

4. Asamblea Legislativa. (2008). Constitución de la República del Ecuador. Decreto Legislativo 0, Registro Oficial 449 de 20-oct-2008, Ultima modificación: 13-jul-2011. Estado: Vigente, Disponible en: http://www.oas.org/juridico/pdfs/mesicic4_ecu_const.pdf

5. Asamblea Nacional. (2010). Ley Orgánica del Servicio Público. Quito, Pichincha, Ecuador: Secretaría General Jurídica de la Presidencia de la República. 
6. Astawa, I. N., Mantra, I. B. N., \& Widiastuti, I. A. M. S. (2017). Developing Communicative English Language Tests for Tourism Vocational High School Students. International Journal of Social Sciences and Humanities (IJSSH), 1(2), 58-64.

7. Basak, A., \& Khanna, K. (2017). A Study on the Selection Criteria of Different Hotels of Delhi NCR in Accordance to the HR Policies and Market Trends. International Journal of Social Sciences and Humanities (IJSSH), 1(1), 27-38.

8. Bello Andrés. (2016). Significado de Ley. Consultado 23 agosto 2016. Disponible en: http://www.significados.com/ley/

9. Billaiya, R., Malaiya, S., \& Parihar, K. S. (2017). Impact of Socio Economic Trends on Students in Quality Education System. International Journal of Social Sciences and Humanities (IJSSH), 1(1), 16-20.

10. Carbajal Sánchez Bernardo. (2013). Cómo asegurar calidad regulatoria. How to Ensure Regulatory Quality? Revista Digital de Derecho Administrativo, No. 9. Université Paris I Panthéon-Sorbonne; Universidad Externado de Colombia. Disponible en: http://revistas.uexternado.edu.co/index.php/Deradm/article/view/3494/3560

11. Cedeño, M. L. D., Arteaga, M. G. D., Pérez, A. V., \& Arteaga, M. L. D. (2017). Regulatory Framework for Renewable Energy Sources in Ecuador Case Study Province of Manabí. International Journal of Social Sciences and Humanities (IJSSH), 1(2), 29-42.

12. Diógenes C. (2016). Servicios Públicos. Caracas. Venezuela: MINISTERIO DE EDUCACIÓN SUPERIOR. Universidad de Santa María. Facultad sde Derecho. Derecho Administrativo I.

13. Gámez, M. R., Pérez, A. V., Será, A. S., \& Ronquillo, Z. M. (2017). Renewable Energy Sources and Local Development. International Journal of Social Sciences and Humanities (IJSSH), 1(2), 10-19.

14. Ghosh, C. (2017). A Study on-Evaluating Marketing Strategies Adopted by Home Appliance for Economic Development in India. International Journal of Social Sciences and Humanities (IJSSH), 1(1), 9-15.

15. González J, Marcelo P, Pérez A, Velazco D Y, \& Cruz Ignacio. (2008). Nuevas tecnologías basadas en energías renovables; barreras a su inserción y políticas de promoción. Situación eólica en algunos países de Latinoamérica. Documento elaborado a partir del "Seminario de Formadores en Formación de Energías Renovables", Guatemala, Noviembre de 2008.

16. Maba, W. (2017). Teacher's Perception on the Implementation of the Assessment Process in 2013 Curriculum. International Journal of Social Sciences and Humanities (IJSSH), 1(2), 1-9.

17. Maba, W., \& Mantra, I. B. N. (2017). An Analysis of Assessment Models Employed by The Indonesian Elementary School Teachers. International Journal of Social Sciences and Humanities (IJSSH), 1(1), 39 45.

18. Pérez Porto Julián, \& Gardey Ana. (2009). Definición de Ley. Consultado el 23 de agosto de 2016. Disponible en: http://definicion.de/ley/

19. Quisbert E. (2011). Del Desarrollo Sustentable al Desarrollo Sostenible. Apuntes Jurídicos en la Web, consultado 23 julio 2016. Disponible en: http://jorgemachicado.blogspot.com/2009/08/dss.html

20. Rey J F. (2010). Tecnologías para un desarrollo sostenible. Centro de Inmunología Molecular de La Habana, Cuba, 17 páginas.

21. Santamarta J. (2004). Las energías renovables son el futuro. Noticias America Latina, La Insignia. Ambiental.net. WorldWaa.

22. Senplades (2013). Plan Nacional de Desarrollo / Plan Nacional para el Buen Vivir 2013-2017 ISBN-9789942-07-448-5. www.planificacion.gob.ec senplades@senplades.gob.ec

23. Suarez Díaz Reynaldo. (2011). La importancia de la Ley. Consultado el 23 de agosto de 2016. Disponible en: http://www.vanguardia.com/opinion/columnistas/97268-la-importancia-de-la-ley

24. Suparsa, I. N., Mantra, I. B. N., \& Widiastuti, I. A. M. S. (2017). Developing Learning Methods of Indonesian as a Foreign Language. International Journal of Social Sciences and Humanities (IJSSH), 1(2), 51-57.

25. Suryasa, I. W., Prayoga, I. G. P. A., \& Werdistira, I. W. A. (2017). An Analysis of Students' Motivation Toward English Learning As Second Language Among Students In Pritchard English Academy (PEACE). International Journal of Social Sciences and Humanities (IJSSH), 1(2), 43-50.

26. Vázquez Pérez Antonio. (2012). Las energías renovables desde una visión normativa jurídica. Tesis de grado para la obtención del título de Licenciado en Derecho, Repositorio de la Facultad de Derecho. Universidad de Oriente

Cedeno, M. L. D., Arteaga, M. G. D., Perez, A. V., \& Arteaga, M. L. D. (2017). Regulatory framework for renewable energy sources in Ecuador case study province of Manabi. International Journal of Social Sciences and Humanities, 1(2), 29-42. https://doi.org/10.29332/ijssh.v1n2.33 
27. Viamonte E, \& Colectivo de autores. (2007). Derecho Ambiental Cubano. Editorial Felix Varela. Segunda edición actualizada y aumentada, Universidad de La Habana. Cuba. ISBN 978-959-07-0434-5.

28. Xavier G C. (1995). Las Energías Renovables: su papel en la Cooperación y en la elaboración de un Modelo de Desarrollo Sostenible. ICAI, Ingenieros Sin Fronteras, Madrid, Documento interno CIEMAT.

\section{Biography of Authors}

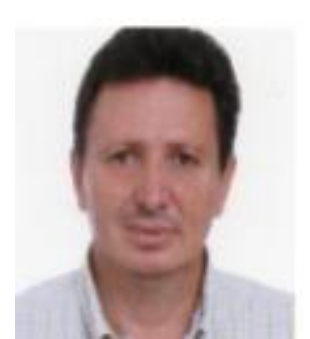

Electrical Engineer, Magister, head teacher Universidad Técnica de Manabí, In the race of Electricity of the Faculty of Mathematics, Physics, and Chemistry.

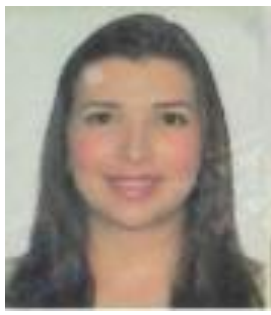

Graduated from law school At the Universidad Catolica of Guayaquil

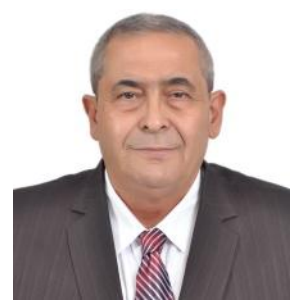

Lawyer, Master, student of the doctoral program of the University of Alicante Spain, Specialist in energy regulatory framework and local development

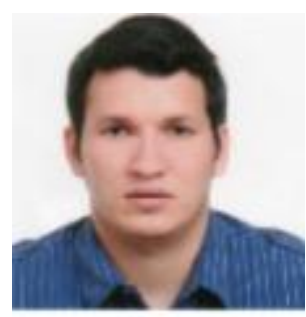

Graduated From Universidad de Especialidades Espiritu Santo (UEES) Faculty of Telecommunications And Electronics Systems in Guayaquil. 